\title{
SYGDOM, HELBREDELSE, SUNDHED
}

Titelbilledet på bind VI af Encyclopédie française, "Lêtre humain", der blev publiceret under ledelse af Leriche, repræsenterer sundheden i skikkelse af en atlet, en kuglestøder. Dette enkle billede forekommer os at være lige så oplysende som alle de følgende sider, der er viet til beskrivelsen af det normale menneske. Vi vil nu samle alle vore refleksioner, der ligger spredt i tidligere fremstillinger og kritiske undersøgelser, og bruge dem til at skitsere en definition af sundhed.

Hvis man anerkender, at sygdommen forbliver en slags biologisk norm, indebærer det, at den patologiske tilstand ikke kan siges at være absolut anormal, men anormal i forhold til en bestemt situation. Omvendt er det at være sund og det at være normal ikke fuldstændigt ækvivalente, for det patologiske er selv en slags normal. At være sund er ikke kun at være normal i en given situation, men også at være normativ i denne situation og eventuelt $i$ andre situationer. Det der karakteriserer sundheden, er muligheden for at gå ud over den norm, der definerer, hvad der i et givent øjeblik er normalt, muligheden for at tolerere overtrædelser af den vanemæssige norm og oprette nye normer i nye situationer. Med én nyre er man stadigvæk normal i et miljø og et system med givne fordringer. Men man kan ikke længere tillade sig den luksus at miste en nyre, man må passe på den 
og på sig selv. Den sunde medicinske fornufts forskrifter er så velkendte, at man ikke leder efter nogen dybere mening med dem. Og alligevel, hvor er det nedværdigende og vanskeligt at adlyde en læge, der siger: Pas godt på Dem selv! [Ménagez-vous !] "Det er nemt nok at sige: pas på Dem selv, men jeg skal passe mine huslige pligter [j'ai mon ménage]", sagde en husmor i hospitalskonsultationen, uden dermed at mene noget som helst ironisk eller semantisk. En husholdning [ménage], det kan måske være en syg ægtemand eller et sygt barn, iturevne bukser, som skal repareres om aftenen, når barnet er i seng, for det har kun ét par bukser, og det kan være en lang tur for at hente brød, når den sædvanlige bager er lukket grundet brud på reglementet, etc. At passe på sig selv, hvor er det vanskeligt, når man levede uden at vide, hvornår der var noget at spise, uden at vide om trappen var stejl eller ej, uden at vide hvornår den sidste sporvogn gik, for hvis den var kørt, måtte man gå hjem, selvom vejen var lang.

Sundhed er en margen af tolerance over for miljøets upålidelighed. Men er det ikke absurd at tale om miljøets upålidelighed? Det kan nok give mening for menneskets sociale miljø, hvor institutionerne i grunden er usikre, konventioner kan tilbagekaldes, moder skifter med lynets hastighed. Men det kosmiske miljø, det animalske miljø i det hele taget, er det ikke et system af mekaniske, fysiske og kemiske konstanter, består det ikke af invarianter? Rigtignok består dette miljø, som videnskaben definerer, af love, men disse love er teoretiske abstraktioner. Det levende væsen lever ikke blandt love, men blandt skabninger og begivenheder, som varierer disse love. Det, der bærer fuglen, er den gren den sidder på, og ikke elasticitetens love. Hvis vi reducerer grenen til elasticitetens love, bør vi ikke længere tale om fuglen, men om kolloidale ${ }^{1}$ løsninger. På et sådant analytisk abstraktionsniveau er der ikke længere tale om miljø for et levende væsen, og derfor heller ikke om sundhed eller sygdom. Ligeledes er det, som ræven spiser, et hønseæg og ikke æggehvidestoffers kemi eller embryologiens love. Fordi et konkret levende væsen lever i en verden af konkrete objekter, lever det i en verden af mulige omskiftelser. Intet er tilfældigt, men alt sker i form af begivenheder. Her ser vi, hvorfor miljøet er upålideligt. Dets upålidelighed er ganske enkelt dets uophørlige tilbliven, dets historie.

1 [Et kolloid (af gr. kolla, lim) er et stof der består af ultrasmå partikler.] 
For det levende væsen er livet derfor ikke en monoton deduktion, en retlinjet bevægelse, livet er uvidende om geometriens rigiditet, det er forhandling eller sammenstød (hvad Goldstein kalder Auseinandersetzung) med et miljø, hvor der er flugtveje, huller, undvigelser og uventede modstande. Lad os gentage det endnu en gang: Vi bekender os ikke til den indeterminisme ${ }^{2}$, der har så stor medvind for tiden. Vi fastholder at et levende væsens liv, selv en amøbes, kun kender kategorierne sundhed og sygdom på et erfaringsmæssigt plan (hvilket først og fremmest er en afprøvning i ordets affektive forstand), og ikke på videnskabens plan. Videnskaben forklarer erfaringen, men den annullerer den ikke af den grund.

Sundhed, det er en mængde sikkerheder og forsikringer (hvad tyskerne kalder Sicherungen), sikkerheder i nutiden og forsikringer for fremtiden. Ligesom der findes en psykologisk forsikring, som ikke er indbildning, findes der en biologisk forsikring, som ikke er grænseløs, og som er sundheden. Sundhed er en sikkerhedsreserve af reaktionsmuligheder. I almindelighed holder livet sig inden for sine muligheder, men viser sig efter behov at være sin egen forventede kapacitet overlegen. Dette er evident ved forsvarsreaktioner af den inflammatoriske type. Hvis kampen mod en infektion blev vundet øjeblikkeligt, ville der ikke opstå nogen inflammation. Hvis de organiske forsvar med det samme blev tvunget til at agere, ville der heller ikke være nogen inflammation. Hvis der er inflammation, er det fordi det anti-infektiøse forsvar på en gang er blevet overrumplet og immobiliseret. At være ved godt helbred betyder at kunne blive syg og så komme sig, det er en biologisk luksus.

Omvendt er det særegent for sygdommen, at den er en reduktion af tolerancemargenen for miljøets upålidelighed. Og idet vi taler om reduktion, mener vi ikke, at vi bliver ramt af den kritik, vi har leveret af Comte og Cl. Bernards opfattelser. Denne reduktion består i, at den syge kun kan leve i et nyt miljø, og ikke blot blandt nogle dele af det tidligere. Det er, hvad Goldstein så meget klart. I grunden udtrykker folks frygt for sygdommenes komplikationer ikke andet end denne erfaring. Man tager sig mere af den sygdom, som en given sygdom risikerer at kaste os ud i, end af sygdommen selv, for der er snarere en hurtigt udviklet rækkefølge af sygdomme end en

[Indeterminisme: lære om menneskets frie (ikke årsagsbestemte) vilje.] 
sygdomskomplikation. Hver sygdom reducerer evnen til at konfrontere de andre sygdomme og tærer på den oprindelige biologiske forsikring, uden hvilken der ikke engang ville være noget liv. Mæslinger, det er ikke noget, for det er den bronkiale lungebetændelse man frygter. Syfilis er frygtet, men først efter at den har sat sig på nervesystemet. Diabetes er ikke så alvorlig, så længe den bare nøjes med at udskille sukker i urinen. Men koma? Eller koldbrand? Og hvad sker der, hvis et kirurgisk indgreb bliver nødvendigt? Blødersygdommen betyder virkelig ikke noget, så længe den syge undgår traumatiske skader. Men hvem er beskyttet mod blødninger, medmindre man vender tilbage til en intrauterin ${ }^{3}$ tilværelse? Og selv da!

Filosoffer strides om, hvorvidt det levende væsens fundamentale stræben handler om selvopholdelse eller ekspansion. Her kunne det se ud til, at medicinsk erfaring kan levere et vægtigt argument i debatten. Goldstein bemærker, at det morbide ønske om at undgå situationer, der eventuelt kan fremkalde katastrofiske reaktioner, er udtryk for et selvopholdelsesinstinkt. Dette instinkt er ifølge ham ikke livets generelle lov, men en lov for et indskrænket liv. Den sunde organisme søger ikke så meget at opretholde sig selv i sin aktuelle tilstand og miljø, som den søger at realisere sin natur. Men dette kræver, at organismen, idet den konfronterer risici, accepterer muligheden af katastrofiske reaktioner. Det sunde menneske lister sig ikke væk fra problemer, der rejser sig ved til tider pludselige omvæltninger af dets vaner, selv når vi med vane forstår et fysiologisk fænomen; det måler sin sundhed på evnen til at overvinde organiske kriser for at oprette en ny orden (Gurwitsch 107).

Mennesket oplever ikke sig selv som et virkelig sundt menneske (og dét er netop sundhed), medmindre det føler sig mere end normal, det vil sige: tilpasset miljøet og dets krav, men desuden også normativ, i stand til at følge nye livsnormer. Det er åbenbart ikke med det udtrykkelige formål at give mennesker denne følelse, at naturen har konstrueret deres organismer med en sådan ødselhed: for meget nyre, for meget lunge, for meget biskjoldbruskkirtel, (W. B. Cannon) for meget bugspytkirtel, endog for meget hjerne - hvis menneskeligt liv skulle indskrænkes til blot at være et vegetativt liv. En sådan måde at tænke på afslører den mest naive 
finalisme. ${ }^{4}$ Men det har altid været sådan: Mennesket føler sig båret af en overflod af midler, som det er normalt for det at sløse med. I modsætning til visse læger, der er for tilbøjelige til at se forbrydelser i sygdommene (eftersom de berørte på grund af umådeholdenhed eller forsømmelse selv bærer en del af ansvaret), er vi af den opfattelse, at evnen og fristelsen til at blive syg er en væsentlig karakteristik af den menneskelige fysiologi. Idet vi modulerer en sætning af Valéry, har vi sagt, at et muligt misbrug af sundhed er en del af sundheden.

For at bedømme det normale og det patologiske må man ikke begrænse det menneskelige liv til vegetativt liv. Man kan leve med mange misdannelser eller lidelser, men man kan intet stille op med sit liv, eller også kan man altid gøre noget, og det er i denne forstand, at enhver af organismens tilstande, hvis de er tilpasset påtvungne omstændigheder, ender med, for så vidt de er forenelige med liv, i grunden at være normale. Men denne normalitet bliver betalt med afståelsen af al eventuel normativitet. Mennesket, selv det fysiske menneske, er ikke begrænset til sin organisme. Mennesket, som har forlænget sine organer ved hjælp af redskaber, ser kun sin krop som en ressource for alle mulige midler til handling. Så det er uden for kroppen, man skal kigge for at bedømme, hvad der er normalt eller patologisk for kroppen selv. Med en defekt som astigmatisme ${ }^{5}$ eller nærsynethed ville man være normal i et landbrugs- eller hyrdesamfund, men anormal blandt søfolk eller piloter. Fra det øjeblik menneskeheden teknisk forstørrede sine samfærdselsmidler, føler man sig anormal, når man véd, at man nægtes adgang til visse aktiviteter, som for menneskearten er blevet både et behov og et ideal. Følgelig forstår man ikke rigtig, hvordan det samme menneske med de samme organer på forskellige tidspunkter i menneskelige miljøer føler sig normal eller anormal, medmindre man forstår, hvordan den organiske vitalitet hos mennesket udfoldes som teknisk plasticitet og som ønske om at dominere miljøet.

4 [Finalisme: Filosofisk og teologisk teori om at naturlige processer (som fx arternes udvikling) er formålsbestemte. (Bliver undertiden opfattet som det modsatte af mekanistiske teorier.)]

[astigmatisme: bygningsfejl i øjet.] 
Hvis man nu vender tilbage fra disse analyser til den konkrete fornemmelse af den tilstand, de har forsøgt at definere, forstår man, at sundheden giver mennesket en følelse af sikkerhed i livet, som ikke anviser sig selv nogen begrænsning. Valere, som [fransk] valeur [værdi] er udledt af, betyder på latin at være ved godt helbred. Sundhed er en måde at bemestre tilværelsen på, idet man føler sig, ikke kun som dens ejer eller bærer, men også - hvis nødvendigt - som værdiskaber, grundlægger af vitale normer. Deraf denne forførelse, som i dag stadigvæk er virksom i billedet af atleten - en forførelse, som nutidens begejstring for en rationaliseret sport kun forekommer os at være en bedrøvelig karikatur af. ${ }^{6}$

"Sygdom, helbredelse, sundhed" er et oversat uddrag af kapitlet "Maladie, guérison, santé" i Georges Canguilhem, Le normal et le pathologique, Paris: Presses Universitaires de France, 2015, 170-175.

Oversat af Rolf Reitan.

\section{LITTERATUR}

Cannon, W. B. La sagesse du corps, kap. XI: La marge de sécurité dans la structure et les fonctions du corps, Paris, 1946. [Amerikansk udgave, The Wisdom of the Body, New York: Norton \& Company 1939, kap. 15.] Gurwitsch, Aron. "Le fonctionnement de l'organisme d'après K. Goldstein". Journal de Psychologie (1939): 107.

6 Man vil måske indvende, at vi har en tendens til at forveksle sundhed med ungdom. Vi glemmer imidlertid ikke, at alderdommen er et normalt stadium i livet. Men blandt ældre i samme alder, vil den være sund, som evner at tilpasse sig eller blive helbredt for organiske mangler, som en anden ikke kan tilpasse sig eller blive helbredt for, for eksempel en god og solid sammenvoksning af en brækket lårbenshals. Den smukke olding er ikke kun en poetisk fiktion. 